\title{
Organizacja i funkcjonowanie duszpasterstwa wyznania prawosławnego w Wojsku Polskim na Zachodzie w latach 1943-1945
}

\author{
Joanna Gabriela Pyczel \\ Instytut Historyczny Uniwersytetu Wrocławskiego, Polska \\ ORCID: 0000-0002-0228-0670 \\ pyczeljoanna@gmail.com
}

\begin{abstract}
J. G. Pyczel, Organization and functioning of the Orthodox ministry in the Polish Army in the West in the years 1943-1945,
\end{abstract} Elpis, 22 2020: 9-15.

\begin{abstract}
In 1943 significant change occurred in the history of the Orthodox military pastoral ministry in the Polish Armed Forces in the West. It was related to the appointment of a military Orthodox bishop. This function was taken over by the former Bishop of Grodno-Nowogrodek Sawa (Sovetov). He was considered to be the only hierarch of the Polish Autocephalous Orthodox Church, which remained faithful to the principles of autocephaly. His efforts to defend the independence of Polish Orthodoxy were indispensable at the time. The period during which Bishop Sawa performed the function of military Orthodox bishop in Great Britain and on the continent contributed to the development of this religion's ministry. He rose to the tasks entrusted to him, which was appreciated by the military and political authorities. Shortly after the war, Bishop Sawa was awarded, among others, with the Gold Cross of Merit with Swords. As a military Orthodox bishop he proved himself as a zealous patriot and tireless priest who tried to provide proper spiritual care to all Polish soldiers. The purpose of the following article is to present the selection process of a military Orthodox priest in the Polish Armed Forces in the West, the circumstances in which the decision was made to appoint Bishop Sawa, his actions and the difficulties he had to overcome during his ministry.
\end{abstract}

\begin{abstract}
Streszczenie: W 1943 r. doszło do istotnej zmiany w dziejach wojskowego duszpasterstwa prawosławnego w Polskich Siłach Zbrojnych na Zachodzie. Była ona związana z mianowaniem wojskowego biskupa prawosławnego. Funkcję tą objął dawny biskup grodzieńsko-nowogródzki Sawa (Sowietow). Uznawano go za jedynego hierarchę Polskiego Autokefalicznego Kościoła Prawosławnego, który pozostawał wierny zasadom autokefalii. Jego działania podejmowane na rzecz obrony niezależności polskiego prawosławia były w tym momencie niezastąpione. Okres pełnienia przez biskupa Sawę funkcji wojskowego biskupa prawosławnego na terenie Wielkiej Brytanii i kontynencie przyczynił się do rozwoju duszpasterstwa tego wyznania. Sprostał powierzonym mu zadaniom, co zostało docenione przez władze wojskowe i polityczne. Już po wojnie, biskup Sawa został odznaczony m.in. Złotym Krzyżem Zasługi z Mieczami. Jako wojskowy biskup prawosławny dał się poznać jako gorliwy patriota i niestrudzony duszpasterz, który starał się otoczyć należytą opieką duchową wszystkich polskich żołnierzy. Celem poniższego artykułu było przedstawienie przebiegu wyboru wojskowego duszpasterza prawosławnego w Polskich Siłach Zbrojnych na Zachodzie, okoliczności w jakich podjęto decyzję o mianowaniu biskupa Sawy, podejmowanych przez niego działań i trudności, które musiał pokonać podczas swojej posługi.
\end{abstract}

Keywords: bishop, Sawa, Orthodox Christianity

Słowa kluczowe: biskup, Sawa, prawosławie

W 1943 r. doszło do przełomu w dziejach wojskowego duszpasterstwa prawosławnego w Polskich Siłach Zbrojnych na Zachodzie. Dotyczył on mianowania wojskowego biskupa prawosławnego. Funkcję tą objął dawny biskup grodzieńsko-nowogródzki Sawa (Sowietow). Od 1940 r. przebywał na terenie Stanów Zjednoczonych, gdzie podejmował rozliczne działania na rzecz obrony niezależności Kościoła prawosławnego w Polsce. W trakcie pobytu za oceanem pozostawał $\mathrm{w}$ bliskich relacjach $\mathrm{z}$ przedstawicielami władz polskich na uchodźstwie. W ramach prowadzonej działalności, jeszcze w 1941 r., wyraził protest przeciwko łamaniu autokefalii polskiej przez niemieckich i radzieckich okupantów (IPMS, A.XII.28.17A, A). Jego postawa wzbudziła znaczny oddźwięk i respekt wśród emigrantów, pracowników polskich placówek dyplomatycznych w Stanach Zjednoczonych i rządu RP na uchodźstwie. W dokumencie Referatu Wyznaniowego MSW z tamtego okresu można przeczytać m.in., że: „Egzamin $\mathrm{z}$ umiejętności przeprowadzania tego rodzaju akcji zdał biskup Sawa w Ameryce, gdzie w oparciu o życzliwość patriarchy Konstantynopola Beniamina potrafił pozyskać dla polskiej myśli wyznaniowej szerokie koła duchowieństwa protestanckiego oraz prawosławnego, przeciwstawić się działalności egzarchy Patriarchy Moskiewskiego i uniemożliwić mu jako czynnikowi politycznemu jakiekolwiek poważniejsze kontakty" (IPMS, A.11.254/2, B). W pochlebny sposób o biskupie Sawie wyrażał się także ambasador Jan Ciechanowski. W swojej notatce w zwięzly sposób określił sylwetkę duchownego: „Stosunek do państwa polskiego jest całkowicie lojalny. Stoi na stanowisku autokefalii polskiej i przynależności ziem wschodnich do Polski. Zasługuje na zaufanie" (IPMS, A.9.V.38, B). Podobnie pozytywną opinię na temat hierarchy miał prof. Klemens Jędrzejewski. Uważał wręcz, że hierarcha jest 
jedynym biskupem prawosławnym, który pozostał wierny Polsce i podejmował działania w ochronie jej interesów. Podkreślał przy tym jego autorytet i fakt, że jest rozpoznawany przez większość wschodnich patriarchów.

Biskup Sawa był członkiem Związku Ziem Wschodnich RP. Należał do Rady Naczelnej organizacji. Jego wystąpienia, w których podkreślał przywiązanie ludności prawosławnej do państwa polskiego, były często wykorzystywane i eksponowane przez władze emigracyjne. Stanowisko to docierało również do kraju. Na łamach podziemnego „Biuletynu Informacyjnego” przekazano informację o oświadczeniu hierarchy, w którym stanowczo krytykował politykę niemieckiego okupanta wobec wyznawców prawosławia. Zwracał w nim także uwagę na brak lojalności wśród niektórych dostojników w kraju. W komunikacie mocno podkreślał, że polska autokefalia może liczyć na jego bezwzględne wsparcie. Odrzucał wszystkie zmiany dokonane przez okupantów. Udzielił przy tym błogosławieństwa wszystkim cierpiącym i pokrzywdzonym wyznawcom prawosławia w Polsce. Oświadczenie biskupa Sawy zainteresowało niemieckie władze okupacyjne. Jego treść stała się przedmiotem ożywionej korespondencji prowadzonej pomiędzy niemieckim MSZ i Głównym Zarządem Bezpieczeństwa Rzeszy.

W ramach prowadzonej działalności hierarcha zwrócił się do władz RP na uchodźstwie z propozycją, aby wystąpiły do patriarchy konstantynopolitańskiego Beniamina o wystosowanie listu, wyrażającego poparcie dla bp. Sawy i uznającego go za jedynego reprezentanta Polskiego Autokefalicznego Kościoła Prawosławnego (dalej: PAKP) na emigracji. Inicjatywa zyskała poparcie m.in. prof. Jędrzejewskiego, który za konieczne uznawał zachowanie ciągłości hierarchicznej PAKP. Jak pisał: „Propozycję X. Biskupa Sawy dodania do tytułu Patriarchy Beniamina „i opiekun Polskiego Kościoła Prawosławnego" należy uzgodnić z Fanarem. A może Fanar znajdzie inne rozwiązanie natury kanonicznej [...] Może biorąc przykład z Metropolity Sergiusza, który nie jest patriarchą, uzyskać dla X. Biskupa Sawy coś w rodzaju tytułu „Strażnika Autokefalicznego Polskiego Kościoła Prawosławnego". Inicjatywa jednak winna wyjść z Fanaru i trzeba aby on uzyskał akceptację innych patriarchów Wschodu. Chodzi nie o formę, lecz o sam fakt podtrzymania hierarchicznej budowy Polskiej Cerkwi Prawosławnej dla nas bardzo ważnej, chociażby ze względów propagandowych" (IPMS, A.XII.28.17A, A). Dnia 27 kwietnia MSZ skierowało do Stambułu wytyczne zarządzające podjęcie kroków, które doprowadziłyby do wydania przez patriarchę ekumenicznego aktu specjalnego dotyczącego biskupa Sawy. W grudniu 1942 r. odbyła się audiencja ambasadora RP Michała Sokolnickiego w Ankarze. W trakcie jej trwania patriarcha Beniamin pozytywnie odniósł się do prośby przedstawiciela władz RP na uchodźstwie i udzielił biskupowi Sawie specjalnego błogosławieństwa jako hierarsze polskiemu.

Biskup Sawa, pełniąc funkcję hierarchy PAKP, otrzymywał miesięczne wynagrodzenie od władz na uchodźstwie. Było ono wypłacane $\mathrm{z}$ funduszy MSW. W ramach prowadzonej działalności nawiązał współpracę z polskimi placówkami dyplomatycznymi w Stanach Zjednoczonych. Biskup mocno zaangażował się w akcję mającą na celu ochronę autokefalii kościoła prawosławnego w Polsce. Do zakresu podległych mu zadań należało m.in. rozpowszechnianie informacji dotyczących autokefalii pośród duchowieństwa amerykańskiego. Ważne było nawiązanie kontaktu z egzarchą patriarchy konstantynopolitańskiego i klerem anglikańskim. W lipcu 1943 r. biskup Sawa wystosował list do patriarchy Beniamina. Prosił w nim o poparcie arcybiskupa Nowego Rzymu w kwestiach związanych $\mathrm{z}$ odbudową autokefalii w Polsce. W dokumencie podkreślał, że przeciwnicy Polski starają się doprowadzić do rozbicia jedności PAKP, wykorzystując w tym celu czynnik narodowościowy. Równocześnie w pochlebny sposób wypowiadał się na temat polskich władz na uchodźstwie, prezydenta W. Raczkiewicza i premiera gen. W Sikorskiego. Chwalił ich za pozytywny stosunek do ludności prawosławnej. Zaznaczał, że zarówno kapłani jak i wierni wyznania prawosławnego, pozostają wierni wobec Polski (Filipow, Suchcitz, 1997).

W 1943 r. władze RP na uchodźstwie zaczęły rozważać przekazanie biskupowi Sawie funkcji na terenie Europy. Zastanawiano się nad możliwością sprowadzenia hierarchy z USA na teren Wielkiej Brytanii. Miało być to korzystne z kilku powodów. Przede wszystkim brano pod uwagę ówczesne stosunki z duchowieństwem Kościoła anglikańskiego. W tamtym okresie za szczególnie niepokojące uznawano możliwe zbliżenie pomiędzy stroną anglikańską i Rosyjskim Kościołem Prawosławnym (Grzybowski, 2016, s. 292). Z zainteresowaniem monitorowano wyjazd abp. Yorku dr Gabretta do Moskwy, gdzie miał wziąć udział w obradach Soboru Biskupów. Niepokój strony polskiej wzbudziła informacja o możliwej wizycie metropolity Mikołaja (Jaruszewicza) w Wielkiej Brytanii. Wyrażano obawę, że strona radziecka będzie starała się wykorzystać Kościół rosyjski w celach politycznych. Uznawano, że przywrócenie patriarchatu moskiewskiego pozwoli na skierowanie ataków w stronę autokefalii polskiej, co w dalszej perspektywie doprowadziłoby do podporządkowania polskiego prawosławia Moskwie. W ówczesnej sytuacji biskupa Sawę uznawano za jedynego hierarchę PAKP, który pozostawał wierny zasadom autokefalii. Jego działania podejmowane na rzecz obrony niezależności polskiego prawosławia były w tym momencie niezastąpione (IPMS, A.11.252.2). Dodatkowo, zgodnie z notatką Wydziału Politycznego MON, przyjazd biskupa Sawy do Londynu pozwoliłby na poprawienie wizerunku polskiej polityki wobec prawosławnych, nadwyrężonej m.in. po incydencie z Franciszkiem Wicenikiem (prawosławnym kapelanem WP w latach 1941-1943, który okazał się hochsztaplerem.). Strona brytyjska nie wyraziła sprzeciwu wobec przyjazdu hierarchy do Londynu. Wyrażano jedynie wątpliwości, czy sprawdzi się w nowo powierzonej funkcji.

Dnia 19 września 1943 r. biskup Sawa wyleciał do Londynu. Jego podróż była możliwa dzięki uzyskaniu wizy wojskowej. Po przybyciu na miejsce niemal od razu zaangażował się w życie kościelne i społeczne. Dnia 27 września spotkał się z prezydentem W. Raczkiewiczem, 
któremu zdał sprawozdanie $\mathrm{z}$ działalności prowadzonej w Stanach Zjednoczonych (Piotrowski, 2004, s. 104). Od 17 października do 24 listopada uczestniczył w licznych spotkaniach i uroczystościach. Głównie widywał się z hierarchią i klerem Kościoła anglikańskiego, z którymi odprawiał nabożeństwa (IPMS, A.XII.28.17A, B). Biskup uczestniczył m.in. w nabożeństwie na Westminister Abbey, gdzie obecna była również królowa Elżbieta. Wziął także udział w spotkaniu w Klubie Greckim, którego organizatorem był egzarcha patriarchy ekumenicznego metropolita Germanos. Informacja o jego przybycie do Anglii była komentowana za oceanem. Odniósł się do niej m.in. prof. Jędrzejewski. W liście do hierarchy napisał: „X Beniamin puścił pogłoskę, że Ekscelencja wyjechała do Londynu, aby tam spotkać się z metropolitą Mikołajem i, ,pomiritsia s russkoj tzerkovju-Materju". Te wieści dotarły do Anglików i był u mnie w tej sprawie P. Anderson" (IPMS, A.9.38). Wraz z przybyciem hierarchy do Londynu stała się aktualna kwestia przekazania mu stanowiska w strukturach wojskowych albo politycznych. Początkowo nie posiadano jednak określonego planu co do pozycji, którą miałby zająć. Zakładano, że można go wykorzystać m.in. do kontaktów z duchowieństwem anglikańskim, ponieważ obawiano się jego zbliżenia do patriarchatu moskiewskiego, kwestionującego niezależność polskiej autokefalii. Ostatecznie stwierdzono, że najlepszym rozwiązaniem będzie powierzenie bp. Sawie funkcji szefa duszpasterstwa wojskowego wyznania prawosławnego w Polskich Siłach Zbrojnych (Grzybowski, 2016, s. 294-295).

Podjęcie takiej decyzji było uzasadnione wieloma argumentami. Jednym z głównych była wzrastająca liczba wyznawców prawosławia służących w PSZ. Wówczas ponad 2 tysiące żołnierzy prawosławnych nie było objętych stałą opieką duszpasterza. Mianowanie biskupa Sawy naczelnym kapelanem wyznania prawosławnego nie wymagało formalnego utworzenia odrębnej jednostki organizacyjnej. Decyzja ta była jednak istotna ze względów politycznych. Było to posunięcie rangi państwowej, na które zwróciłyby uwagę czynniki zewnętrzne. Podczas prowadzonych rozmów systematycznie przypominano, że mianowanie biskupa Sawy umożliwiłoby nawiązanie silnych kontaktów z Kościołem anglikańskim i protestanckim. Umocniłoby to również pozycję kraju w relacjach z patriarchą ekumenicznym (Grzybowski, 2016, s. 295). Do propozycji mianowania bp. Sawy szefem duszpasterstwa wojskowego wyznania prawosławnego pozytywnie odniósł się m.in. Referat Wyznaniowy MSW. Swoje poparcie wyrażał także kierownik Działu Narodowości MSW dr Olgierd Górka. Wyrażał on przekonanie, że objęcie przez bp. Sawy stanowiska biskupa polowego będzie miało szczególnie istotne znaczenie ze względów politycznych. Swoje stanowisko przedstawił w notatce przygotowanej dla ministra spraw wewnętrznych: „W obecnej sytuacji jest jedynym polskim duszpasterzem prawosławnym w Wielkiej Brytanii, a mianowanie go nie biskupem tylko kapelanem wbrew przepisom obowiązującym będzie poczytane za krok zwrócony przeciwko prawosławnym. Obecna sytuacja prawna i faktyczna umożliwia tylko jedno rozwią- zanie, tj. powołanie go na biskupa wojskowego w randze generała" (IPMS, A.9.V.38, C).

Olgierd Górka słusznie zakładał, że nominacja zostanie pozytywnie odebrana przez Brytyjczyków i udowodni, że rząd polski na uchodźstwie stosuje równouprawnienie wobec wszystkich obywateli niezależnie od narodowości czy wyznania. Jak podkreślał w notatce: ,jasne jest dla każdego, że nikt z dotychczasowych duchownych na odcinku brytyjskim nie może sprawie polskiej oddawać większych usług propagandowych, jak bp Sawa. Oczywiście rolą swą może spełniać jedynie po postawieniu go organizacyjnie $\mathrm{w}$ ramach państwa polskiego, a nie jako nieokreślony duchowny o nieokreślonym charakterze i nieokreślonych środkach dochodu" (IPMS, A.9.V.38, C). Oczekiwano przy tym, że informacja o mianowaniu wojskowego biskupa prawosławnego dotrze do obywateli polskich wyznania prawosławnego, pozostających na terenie kraju. Objęcie stanowiska przez bp. Sawę stałoby się ważnym argumentem, pozwalającym na odparcie rosyjskiej propagandy i zarzutów Kremla dotyczących nietolerancji religijnej w Polsce. Kwestię tą poruszył kierownik Działu Narodowości MSW, pisząc: „Na gruncie angielskim istnieje wybitna wrażliwość na zagadnienia religijne. Tą oceną kierował się widocznie rząd sowiecki, stwarzając pozory wolności religijnej w Sowietach przez powołanie instytucji Patriarchatu Moskiewskiego. W tych warunkach nominacja prawosławnego biskupa wojskowego w Wojsku Polskim odbiera jakiekolwiek możliwości zarzutu ze strony sowieckiej" (Grzybowski, 2016, s. 297).

W sprawie dotyczącej mianowania biskupa wojskowego wyznania prawosławnego pojawiały się także sceptyczne głosy. Jednomyślność uzyskano w kwestii przekazania bp. Sawie opieki nad żołnierzami prawosławnymi w Wojsku Polskim. Nie udało się jednak wypracować wspólnego stanowiska co do tego, czy powinien on zająć stanowisko kapelana czy też biskupa wojskowego. Przeciwny objęcia przez niego urzędu biskupa wojskowego miał być m.in. biskup polowy Wojska Polskiego bp Józef Gawlina (Filipow, Suchcitz, 1997). Stanisław Paprocki, sprawujący funkcję kierownika Działu Narodowości MID, stosunkowo szybko uzasadnił bezpodstawność jego argumentów „Na wczorajszym posiedzeniu komisji MSZ dowiedziałem się, że na skutek zastrzeżeń ks. biskupa Gawliny (sic!) p. minister Obrony Narodowej gen. Kukiel jakoby w porozumieniu z ks. ministrem Kaczyńskim ma zamiar zaproponować biskupowi Sawie stanowisko szefa duszpasterstwa prawosławnego Wojska Polskiego, a nie jak jednomyślnie doradzała konferencja rzeczoznawców w MWRiOP tydzień temu - Wojskowego Biskupa Prawosławnego, tytuł przewidziany Dekretem Prezydenta RP o stosunkach Kościoła prawosławnego do Państwa [...] Sprzeciwy kleru katolickiego niczym nieumotywowane, a znane ze smutnej tradycji dziejów przedrozbiorowych, nie powinny rozstrzygać w sprawie, która dotyczy żywotnych interesów Rzeczypospolitej [...]. Ze względu na wypadki rozgrywające się w Moskwie (wskrzeszenie Patriarchatu) oraz sytuację Kościoła prawosławnego w kraju (pod okupacją) w bezspornym interesie Państwa jest, aby również prestiżowe 
stanowisko biskupa Sawy na zewnątrz wzmocnić jak najbardziej" (IPMS, A.9.V/38, D).

Podobne stanowisko w tej sprawie przyjęli pracownicy MSW. Dział Narodowości przygotował notatkę, w której twierdzono, że: „Biskup Sawa jest jedynym biskupem prawosławnym polskim na wychodźstwie i może on odegrać bardzo pozytywną rolę $\mathrm{w}$ obronie polskiego prawosławia wobec obcych. Tym bardziej nie należy go zrażać, kierując się względami, które nie mogą mieć zastosowania. Więc przede wszystkim nie może wchodzić w rachubę czynnik prestiżowy międzywyznaniowy. Konfesyjne podejście ze strony katolickiej może nas drogo kosztować w zakresie politycznym. Nikt i nigdzie nie zrozumie, że obok biskupa polowego katolickiego w wojsku polskim nie może istnieć wojskowy biskup prawosławny, rabin naczelny, itp. to wymagania zarówno obiektywnej sprawiedliwości, jak i istniejących przepisów prawnych. Decydującym momentem są względy natury politycznej. Przemawiają one za szybką i niecierpiącą zwłoki nominacją biskupa Sawy wojskowym biskupem prawosławnym [...]. Niezrealizowanie tego zamierzenia może nas kosztować politycznie na gruncie obcym, a tym bardziej zrazić do Państwa Polskiego przedstawicieli innych wyznań wśród obywateli polskich. Tym bardziej zrazi to zainteresowanego biskupa Sawę, który z całą lojalnością i poczuciem obywatelstwa stanął do dyspozycji rządu" (IPMS, A.9.V/38, E).

Ostateczne stanowisko w tej sprawie udało się wypracować 5 listopada 1943 r., podczas posiedzenia Rady Ministrów. Uchwalono wówczas wniosek do ministra obrony narodowej o mianowanie biskupa Sawy wojskowym biskupem prawosławnym. Jedyny sprzeciw w tej sprawie zgłosił minister wyznań religijnych, powołujący się w swojej decyzji na względy kanoniczne. W przyjętej przez prezydium Rady Ministrów uchwale, napisano: „Rząd RP jest w zasadzie gotów powołać ks. biskupa Sawę na Wojskowego Biskupa Prawosławnego [...]. Biorąc jednak pod uwagę niemożliwość spełnienia wymagań kanonicznych dekretu z powodu znajdowania się metropolity autokefalicznego kościoła prawosławnego polskiego pod okupacją niemiecką, Rada Ministrów poleca ministrowi obrony narodowej przeprowadzenie procedury mianowania biskupa Sawy p.o. prawosławnego biskupa prawosławnego" (IPMS, A.XII.28/17A, C). Jako uzasadnienie wniosku przedstawiano nie tylko względy wojskowe, ale także polityczne. Przede wszystkim zwracano uwagę na fakt, że żołnierze wyznania prawosławnego - w przeciwieństwie do kolegów innych wyznań- nie mają własnej organizacji duszpasterskiej. Podkreślano, że mianowanie biskupa prawosławnego „będzie odpowiadało zasadniczemu stanowisku politycznemu Rządu, stojącego na gruncie integralności ziem Rzeczypospolitej Polskiej” (IPMS, A.XII.28/17A, D).

Dnia 20 listopada 1943 r. biskup Sawa został mianowany generałem brygady. Do objęcia funkcji wojskowego biskupa prawosławnego z siedzibą w Londynie przystąpił 29 listopada br. Zarówno mianowanie go biskupem wojskowym wyznania prawosławnego, jak i nadanie mu stopnia generała brygady okazało się być trafionym posunięciem. Znalazło to swoje odzwierciedlenie w publi- kacjach prasy brytyjskiej i polskiej. W pochlebny sposób o biskupie Sawie i podejmowanych przez niego działaniach pisano m.in. w ukazującym się w Warszawie czasopiśmie „Wschód”, gdzie został określony jako „wierny syn Rzeczypospolitej”. Objęcie przez nieco funkcji prawosławnego biskupa wojskowego zostało pozytywnie przyjęte przez prawosławnych obywateli polskich, zarówno odbywających służbę wojskową, jak i cywilów. W grudniu 1943 r. żołnierze i duszpasterze tego wyznania złożyli mu życzenia z okazji objęcia stanowiska. Dnia 16 grudnia biskup Sawa wydał swój pierwszy list pasterski do żołnierzy, w którym składał im życzenia z okazji zbliżających się świąt Bożego Narodzenia (Grzybowski, 2016, s. 300302). Objęcie przez niego funkcji biskupa prawosławnego Wojska Polskiego przyczyniło się do rozpoczęcia nowego etapu w dziejach polskiego duszpasterstwa wojskowego tego wyznania. Szczególną uwagę należy zwrócić na fakt, że po stronie aliantów jedynie Polskie Siły Zbrojne posiadały prawosławnego biskupa polowego. Nie posiadały go nawet oddziały jugosłowiańskie czy też greckie (IPMS, A.XII.28.17A, E).

Biskup Sawa sprawował opiekę duszpasterską nad żołnierzami prawosławnymi wszystkich oddziałów Polskich Sił Zbrojnych. Jego siedziba znajdowała się w Londynie, choć jednostki polskie były rozrzucone po różnych częściach świata. Ze względu na oczywiste utrudnienie, przez dłuższy czas zakres jego działalności był ograniczony do terytorium Wielkiej Brytanii. Pracę prawosławnego biskupa polowego rozpoczął w niekorzystnych warunkach bytowych. Zastrzeżenia budziła strona materialna służby duszpasterskiej. Jego biuro było dopiero urządzane, a hierarcha miał problemy z zaopatrzeniem i wyposażeniem swojego stanowiska. Potrzebne mu były dwa pokoje, oficer łącznikowy, podoficer-psalmista i jedna osoba ze służby. Zgodnie z zachowanymi dokumentami sporządzonymi przez władze wojskowe można wywnioskować, że do wiosny 1944 r. nie udało się spełnić żadnego z warunków. Biskup Sawa nie posiadał szat biskupich i wielu rzeczy wykorzystywanych podczas nabożeństw. Znaczący był brak głównego ołtarza w londyńskiej kaplicy. Hierarcha nie posiadał stałego pomieszczenia. Korzystał natomiast z pokoju w budynku, w którym znajdowało się Ministerstwo Obrony Narodowej. Ze względu na istotę zajmowanego stanowiska zapewnione mu warunki były wręcz karygodne. $Z$ powagi sytuacji zdawał sobie sprawę minister wyznań religijnych i oświecenia publicznego. Zwrócił się on do MON o uregulowanie tych kwestii. Był przy tym przekonany, że ówczesny stan rzeczy może negatywnie wpłynąc na wizerunek władz polskich. W jednym z listów napisał: „wytwarza się wśród wybitnych członków Kościoła anglikańskiego, jak i wśród prawosławnych opinia, że władze wojskowe umyślnie nie ułatwiają pracy biskupowi Sawie i są nieprzychylnie ustosunkowane do Kościoła prawosławnego. Za ten nienormalny stan rzeczy obciąża się Rząd Polski” (IPMS, A.XII.28/17A, F). Pewne trudności występowały również podczas organizacji pierwszych wizytacji. Odnosi się do tego fragment listu, skierowanego do kierownika Kancelarii Cywilnej Prezydenta RP Augu- 
sta Zaleskiego, w którym zapisano: „,...] Ponadto przytoczył mi następujący przykład: wyjechał niedawno dla odprawienia nabożeństwa dla prawosławnych lotników na jedną ze stacji lotniczych. Mimo tego, że polski dowódca stacji był należycie o przyjeździe biskupa powiadomiony, nic nie było na jego przyjazd przygotowane, nie wysłano nawet samochodu na dworzec, znacznie od stacji lotniczej oddalony, stawiając biskupa $\mathrm{w}$ bardzo przykrej sytuacji. [...]" (IPMS, A.12.252/3, B).

Mimo wszelkich trudności jakie bp Sawa napotkał po objęciu stanowiska prawosławnego biskupa polowego, udało mu się stosunkowo szybko zorganizować opiekę duszpasterską nad polskimi żołnierzami tego wyznania. W Londynie w St. Michael Royal odprawiał niedzielne nabożeństwa, w których mogli brać udział żołnierze korzystający z urlopów i przepustek. Od 4 do 10 stycznia przebywał w Szkocji, gdzie stacjonowały polskie oddziały. Spotkał się tam z dowódcą Jednostek Wojska w Wielkiej Brytanii - gen. Januszem Głuchowskim. Hierarcha został przyjaźnie powitany przez przedstawicieli Kościoła anglikańskiego w Edynburgu. Został przez nich zaproszony do uczestnictwa w wieczornym nabożeństwie w St. Mary's Cathedral (IPMS, A.V.38). Dnia 5 stycznia br. odprawił nabożeństwo, w którym uczestniczył gen. J. Głuchowski i od 200 do 280 żołnierzy prawosławnych z różnych zakątków Szkocji. Obecni zgodnie twierdzili, że mszę cechował podniosły charakter i odbyła się ona przy udziale zorganizowanego chóru (Odziemkowski, 1998, s. 208-209). W podróży towarzyszyli mu reprezentanci Wydziału Politycznego MON i Wydziału Oświaty i Propagandy Dowództwa JWWB. W związku z tym, poza wizytacjami polskich żołnierzy prawosławnych, biskup Sawa spotykał się z dostojnikami kościelnymi, politykami i dziennikarzami. Podczas wizyty w Szkocji hierarcha przynajmniej dwukrotnie odwiedził koszary marynarki wojennej w Devonport. Odprawiał tam również nabożeństwa. W swoich kazaniach nawoływał żołnierzy do wzorowego wypełniania obowiązków, zarówno żołnierskich, jak i obywatelskich. Stanowiąc przykład swoją patriotyczną postawą, stawał się wzorem do naśladowania dla swoich współwyznawców (Grzybowski, 2015, s. 82-83).

Jednym z głównych problemów, które nowy biskup polowy napotkał na swojej drodze, były stosunki narodowościowe w wojsku. Znaczny odsetek żołnierzy prawosławnych w Wojsku Polskim wywodził się mniejszości narodowych. Zdarzało się, że stawali się oni obiektem obserwacji czynników zewnętrznych, często negatywnie nastawionych wobec polskich władz i wojska na uchodźstwie. Był to temat poruszany w publikacjach prasowych. W wydawanych artykułach poruszano kwestie złego traktowania żołnierzy wyznania prawosławnego w WP. Wykorzystywano w tym celu historię wspomnianego już kapelana Franciszka Wicenika, a także niewyjaśnioną sprawę wydalenia i skazania ks. Grzegorza Kuryłasa (szefa duszpasterstwa wyznania prawosławnego Armii Polskiej na terenie ZSRR). Biskup Sawa wielokrotnie odnosił się do zarzutów dotyczących dyskryminacji żołnierzy prawosławnych. Zaprzeczał jakoby byli oni szykanowani i zmu- szani do nabywania literatury propagandowej podczas nabożeństw. Podkreślał fakt, że przystą̧ili oni do Wojska Polskiego z własnej woli: „Chciałbym podkreślić, że ci żołnierze prawosławni przyszli do Armii Polskiej nie tylko bez jakiegokolwiek przymusu, ale w ogromnej części przedzierając się z narażeniem życia, jedni przez Rumunię, Węgry i Południową Europę, inni przez Litwę i Skandynawię, dążąc wszyscy do szeregów Armii Polskiej we Francji, inni wreszcie znaleźli się w W. Brytanii poprzez Rosję Sow. i Środkowy Wschód" (IPMS, A.XII.28.17B).

Do wzmocnienia propagandy antypolskiej, oskarżającej o dyskryminację wyznaniową i narodowościową w Wojsku Polskim doszło wiosną 1944r. Czynnikiem sprzyjającym owym oskarżeniom była informacja o dezercji kilkudziesięciu żołnierzy polskich, którzy opuścili oddziały macierzyste aby następnie wstąpić do brytyjskiego Ministerstwa Wojny. Wśród 25 dezerterów, znalazło się 14 żołnierzy prawosławnych. Incydent został dostrzeżony i wykorzystany $\mathrm{w}$ celu propagowania propagandy politycznej. Dnia 27 marca 1944 r. centralna agencja prasowa ZSRR podała informacje o dezercji, twierdząc, że była ona następstwem szykan stosowanych wobec mniejszości narodowych i wyznaniowych. Wydarzeniem zainteresowały się także brytyjskie środki masowego przekazu. Jako główną przyczynę incydentu wskazywały nietolerancję narodowościową i religijną. W rzeczywistości istniejący w wojsku konflikt miał charakter społeczny, a nie religijny. W grupie dezerterów dominowali emigranci z krajów Ameryki Południowej. W dużej mierze dominowały w niej osoby o proradzieckich poglądach i uległe wrogiej propagandzie. W ramach działań zapobiegawczych MON przygotowało akcję, mającą na celu poprawienie morale w wojsku, w którą zaangażował się biskup Sawa. W porozumieniu z Kurią Polową WP i duchowieństwem greckokatolickim, przygotował szereg pogadanek i kazań. Miały one doprowadzić do polepszenia stanu ducha żołnierzy. Podczas wywiadu udzielonego prasie brytyjskiej stwierdził, m.in. „Dla mnie jako Biskupa Prawosławnego Diecezji Grodzieńskiej i Nowogródzkiej, a dopiero w czasie wojny Prawosławnego Biskupa Wojskowego Armii Polskiej jest ogromną pociechą, że wśród tych, którzy złamali regulamin wojskowy i znaleźli się w Londynie - wszyscy za wyjątkiem jednego pochodzą z Płd. Ameryki. Jest to dla mnie dowodem, że ci, którzy aż do wojny żyli w naszej społeczności prawosławnej w ramach Państwa Polskiego inaczej odnoszą się do sprawy polskiej, aniżeli ci, którzy Polskę i stosunki Polskie znają z relacji i opowiadań, nie zawsze obiektywnych" (IPMS, A.XII.28.17B). Należy również podkreślić, że biskup polowy spotkał się z uciekinierami aby przekonać ich do powrotu do oddziałów. Do rozmów doszło podczas obiadu, podczas którego biskupowi Sawie udało się nakłonić część żołnierzy do zmiany decyzji. Wzięli oni również udział w odprawionym przez hierarchę niedzielnym nabożeństwie.

W okresie pełnienia obowiązków duszpasterskich przez biskupa Sawę, do oddziałów Wojska Polskiego w Wielkiej Brytanii przystąpili kolejni ochotnicy. Wraz $\mathrm{z}$ ich napływem zwiększyła się także liczba wyznawców 
prawosławia $\mathrm{w}$ formacjach PSZ stacjonujących na terenie Anglii. Zgodnie z zachowanymi materiałami wytworzonymi przez Wydział Polityczny MON, w październiku 1944 r. znajdowało się w nich około 800 prawosławnych i katolików obrząadku wschodniego (Lada, Partacz, 2004, s. 229). Latem br. w szeregach 1 Dywizji Pancernej odbywało służbę 78 wyznawców prawosławia (Wendorff, 1995, s. 173). Znaczna liczba żołnierzy prawosławnych pełniła służbę w wojskach lądowych przy sztabie PSZ, Centrum Szkolenia Artylerii, Komendzie Ośrodka Szkolenia Piechoty i 16 Samodzielnej Brygadzie Pancernej. W służbie lotniczej większość prawosławnych należała do obsługi samolotów i personelu naziemnego. Latem 1944 r. część żołnierzy stacjonujących na terenie Wielkiej Brytanii została wysłana na kontynent. Wzięli oni udział w walkach o Francję, Belgię i Holandię. Uczestniczyły w nich: 1 Dywizja Pancerna i 1 Samodzielna Brygada Spadochronowa. W obu formacjach znajdowali się żołnierze wyznania prawosławnego. Ich liczba stale wzrastała. W listopadzie 1945 r., w 1 Dywizji Pancernej służyło 190 żołnierzy prawosławnych, w tym: 1 oficer, 17 pod-oficerów i 172 szeregowców (Grzybowski, 2016, s. 314-315).

Żołnierze prawosławni, biorący udział w walkach na terenie Europy, byli pozbawieni opieki duszpasterskiej. Oddziały nie dysponowały bowiem kapelanem wojskowym. Rozwiązaniem tej sytuacji była decyzja ministra obrony narodowej gen. M. Kukiela o zarządzeniu organizacji duszpasterskiej w postaci wizytacji odbywanych przez bp. Sawę. Generał w liście do Polskiej Misji Wojskowej przy SHAEF pisał: „Na terenie 1. Dywizji Pancernej znajduje się kilkaset żołnierzy wyznania prawosławnego. Nie korzystają oni w tej chwili z żadnej opieki duszpasterskiej i są właściwie w gorszym położeniu od żołnierzy innych wyznań. Dywizja ma bowiem kapelana rzymskokatolickiego, rabina, który sprawuje opiekę duszpasterską nad żołnierzami-Żydami, nad ewangelikami natomiast opiekę sprawują zastępczo kapelanii brytyjscy" (IPMS, A.XII.28.17D, A). W liście prosił Polską Misję Wojskową o pomoc przy organizacji podróży dla biskupa Sawy i załatwienie wszystkich formalności. Ze względu na problemy zdrowotne biskup polowy nie był $\mathrm{w}$ stanie odwiedzić żołnierzy 1 Dywizji Pancernej przed nadejściem Świąt Bożego Narodzenia. Nabożeństwo w zastępstwie odprawił wówczas ksiądz grecki Constantinides (IPMS, A.XII.28.17D, B).

W 1945 r. wojskowe duszpasterstwo prawosławne wzmocniło się o kolejnego duchownego. Do wojska został przyjęty biskup Mateusz Siemaszko, który podczas okupacji Francji przebywał w Paryżu. Dnia 15 stycznia br., na mocy rozporządzenia ministra obrony narodowej, został mianowany protoprezbiterem wojskowym $\mathrm{w}$ duszpasterstwie wyznania prawosławnego. Dwa dni później zgodnie z decyzją MON zajął stanowisko zastępcy wojskowego biskupa prawosławnego. Dołączenie do wojska biskupa Mateusza znacznie odciążyło bp. Sawę w pracy duszpasterskiej. Pierwsze wspólne nabożeństwo hierarchowie odprawili w Edynburgu w St. Mary's Cathedral w związku ze świętem Jordanu. W uroczystości wzięło udział wielu wojskowych i cywilów prawosławnych. Kapelani wspól- nie otoczyli opieką żołnierzy wyznania prawosławnego, pełniących służbę na terenie Wielkiej Brytanii. Często organizowali wizytacje $\mathrm{w}$ innych miastach, aby zaspokoić potrzeby religijne jak największej ilości żołnierzy. Biskup Mateusz towarzyszył swojemu przełożonemu w licznych rekolekcjach w okresie Wielkiego Postu w 1945 r. Hierarchowie odwiedzili wtedy wiele miast na terenie Anglii i Szkocji (IPMS, A.XII.28.17D, C).

$\mathrm{W}$ dyspozycji londyńskiego duszpasterstwa prawosławnego znajdowała się kaplica przy St. Matthias Church, należąca do Kościoła anglikańskiego. Biskup Mateusz odprawił $\mathrm{w}$ niej m.in. uroczyste nabożeństwo $\mathrm{w}$ święto Bożego Narodzenia w 1945 r. Wiosną 1945 r., w wyniku działań podjętych przez bp. Sawę, w Londynie erygowano polską kaplicę prawosławną św. Mikołaja Cudotwórcy. Znajdowała się ona w St. Matthias Church. Dnia 9 maja br. została poświęcona przez egzarchę patriarchy ekumenicznego metropolitę Germanosa. W każdą niedzielę i święta hierarchowie polscy odprawiali w niej nabożeństwa. Asystowali w nich często: ks. Alexy van der Mensbrugghe i ks. Nikola Nikolic (kapelan oddziałów jugosłowiańskich). Główną grupę wiernych, uczestniczących w mszach byli przebywający na urlopie w Londynie żołnierze 1 Korpusu. W nabożeństwach często brali udział także żołnierze kanadyjscy i amerykańscy wyznania prawosławnego (Grzybowski, 2016, s. 318).

Zarówno biskup Sawa, jak i jego zastępca, z sukcesem łączyli działalność duszpasterską z aktywnością społeczno-polityczną. Dnia 19 lutego 1945 r. Polska Agencja Telegraficzna wydała wspólne oświadczenie bp. Sawy i bp. Mateusza dotyczące ustaleń podjętych podczas konferencji jałtańskiej. Hierarchowie występowali w nim przeciwko „piątemu rozbiorowi” Polski. Dodatkowo bp Sawa prowadził swoją działalność w Związku Ziem Wschodnich. W ramach organizacji prowadził akcję, mającą na celu promowanie lojalnych postaw wśród polskich obywateli wyznania prawosławnego. Szczególną uwagę skupiał na wyznawcach prawosławia, którzy wywodzili się z Kresów Wschodnich. Należ przyznać, że członkostwo bp. Sawy przyniosło pozytywne rezultaty. Hierarcha chętnie udzielał się publicznie w czasie różnych uroczystości organizowanych przez władze polskie na uchodźstwie. Angażował się w różne przedsięwzięcia i wszelkie inicjatywy zarówno społeczne, jak i polityczne. Dnia 7 czerwca 1947 r. uczestniczył w zaprzysiężeniu nowego prezydenta RP na uchodźstwie - Augusta Zaleskiego (Wolsza, 1998, s. 28).

Okres pełnienia przez biskupa Sawę funkcji wojskowego biskupa prawosławnego na terenie Wielkiej Brytanii i kontynencie przyczynił się do rozwoju duszpasterstwa tego wyznania. Niewątpliwie hierarcha spełnił pokładane w nim nadzieje i oczekiwania. Sprostał powierzonym mu zadaniom, co zostało docenione przez władze wojskowe i polityczne. Już po wojnie, biskup Sawa został odznaczony m.in. Złotym Krzyżem Zasługi z Mieczami. Jak napisano w uzasadnieniu: „ks. arcybiskup Sawa od jesieni 1943 r. objął stanowisko wojskowego biskupa prawosławnego w Wojsku Polskim na uchodźstwie i z całym poświęceniem oddał się pracy duszpasterskiej, organizując duszpa- 
sterstwo wojskowe w I i II Korpusie oraz lotnictwie i marynarce. Odwiedzał osobiście i b. często oddziały polskie nie tylko w Szkocji, ale i w Italii i w Niemczech. Niezależnie od tego ks. arcybiskup Sawa wykonywał obowiązki biskupa ordynariusza dla cywilnej ludności prawosławnej, pochodzącej z Polski, oraz brał czynny udział w życiu społecznym, ściśle współpracując z Rządem Polskim w Londynie" (IPMS, A.XII.85/13). Biskup Sawa jako wojskowy biskup prawosławny dał się poznać jako gorliwy patriota i niestrudzony duszpasterz, który starał się otoczyć należytą opieką duchowną wszystkich polskich żołnierzy, walczących z dala od ojczyzny.

\section{Wykaz skrótów}

IPMS - Instytut Polski i Muzeum im. Gen. Sikorskiego PAKP - Polski Autokefaliczny Kościół Prawosławny

\section{Bibliografia}

\section{Materialy archiwalne}

IPMS, A.12.252/3, (A), Ambasada w Londynie, Stosunki między Kościołem Anglikańskim a Kościołem Prawosławnym.

IPMS, A.12.252/3, (B), List ambasady RP w Londynie do A. Zaleskiego, $18 \mathrm{~V} 1944 \mathrm{r}$.

IPMS, A.11.252.2, Notatka Referatu Wyznaniowego Wydziału Politycznego MON w sprawie ks. bpa Sawy, 29 IX 1943 r.

IPMS, A.9.V.38, (A), Ministerstwo Spraw Wewnętrznych, Teczka biskupa prawosławnego Sawy.

IPMS, A.9.V.38, (B), Notatka J. Ciechanowskiego dla MID, MWRiOP, MSW na temat bpa Sawy, 24 IX 1942 r.

IPMS, A.9.V.38, (C), Notatka O.Górki w sprawie bpa Sawy, 14 października $1943 \mathrm{r}$.

IPMS, A.9.V/38, (D), List S. Paprockiego do MSW w sprawie bpa Sawy, 1 października $1943 \mathrm{r}$.

IPMS, A.9.V/38, (E), Notatka Działu Narodowości MSW w sprawie powołania wojskowego biskupa prawosławnego, $14 \mathrm{X}$ $1943 \mathrm{r}$.

IPMS, A.9.38, List K. Jędrzejewskiego do bpa Sawy, 5 listopada $1943 \mathrm{r}$.

IPMS, A.11.254/2, (A), Ministerstwo Spraw Zagranicznych, Sprawy wewnętrzne placówki -Ambasady RP -Londyn.

IPMS, A.11.254/2, (B), Notatka Referatu wyznaniowego MON w sprawie bpa Sawy, 29 września 1943 r.

IPMS, A.V.38, Sprawozdanie z pobytu bpa Sawy w Edynburgu w dniach od 4 do 10 stycznia $1944 \mathrm{r}$.

IPMS, A.XII.28.17, Oddział Ogólny Sztabu Naczelnego Wodza, Referat Wyznań Niekatolickich, Wyznanie Prawosławne.

IPMS, A.XII.28.17A, (A), Referat pt. Sprawa stosunku do moskiewskiej -patriarszej cerkwi prawosławnej, I $1942 \mathrm{r}$.

IPMS, A.XII.28.17A, (B), Krótkie sprawozdanie z dotychczasowej działalaności bpa Sawy w Londynie od 17 października do 24 listopada $1943 \mathrm{r}$.

IPMS, A.XII.28/17A, (C), Notatka Referatu Wyznaniowego Wydziału Politycznego MON w sprawie ks. bpa Sawy, 1 X 1943 r.

IPMS, A.XII.28/17A, (D), Wniosek na Radę Ministrów w sprawie mianowania bpa Sawy wojskowym biskupem prawosławnym oraz Protokoły posiedzeń Rady Ministrów.., t. 6, s. 226.

IPMS, A.XII.28.17A, (E), Notatka MON dla ambasadora RP Raczyckiego, 15 maja $1944 \mathrm{r}$.

IPMS, A.XII.28/17A, (F), List MWRiOP do MON, 11 V 1944 r.
IPMS, A.XII.28.17B, List bpa Sawy do redakcji pisma brytyjskiego, bd.

IPMS, A.XII.28.17D, (A), List gen. M.Kukiela do szefa wysuniętego rzutu Polskiej Misji Wojskowej przy SHAEF, 25 X $1944 \mathrm{r}$.

IPMS, A.XII.28.17D, (B), List Ministra obrony Narodowej do dowódcy 1 Dywizji Pancernej, 21 XII 1944 r.

IPMS, A.XII.28.17D, (C) List Biura Ministra - Wydział Polityczny MON do dowódcy Oddziału Administracyjnego MON, 17 IV 1945 r., oraz Krótkie wiadomości, w : „Polski Żołnierz Prawosławny" 1946, nr 5, s. 8.

IPMS, A.XII.85/13, Wniosek o odznaczenie abp. Sawy, wojskowego biskupa Wojsk Polskich Złotych Krzyżem Zasługi z Mieczami.

\section{Źródła opublikowane, opracowania i artykuły}

Filipow, K., Suchcitz, A. (red.). (1997). Arcybiskup generat brygady Sawa (Jerzy Sowietow). Wybór dokumentów. Białystok-Warszawa: Ośrodek Badań Historii Wojskowej Muzeum Wojska w Białymstoku.

Grzybowski, J. (2015). Działalność duszpasterska wojskowego biskupa prawosławnego Sawy (Sowietowa) w Polskich Siłach Zbrojnych na Zachodzie w latach 1943-1947. Przeglad Historyczno-Wojskowy, 16(67)/1 (251), 75-89. 75-89. Warszawa.

Grzybowski, J. (2016). W stużbie Rzeczypospolitej. Duszpasterstwo wojskowe wyznania prawostawnego $w$ wojsku polskim w latach 1919-1949. Warszawa: Wojskowe Centrum Edukacji Obywatelskiej Im. Płk. Dypl. Mariana Porwita.

Łada, K., Partacz, Cz. (2004). Polska wobec ukraińskich dażeń niepodległościowych w czasie II wojny światowej. Toruń: Centrum Edukacji Europejskiej.

Odziemkowski, J. (1998). Stużba Duszpasterska Wojska Polskiego 1914-1945. Warszawa: Bellona.

Piotrowski, J. (red.). (2004). Dziennik czynności Prezydenta RP Władystawa Raczkiewicza 1939-1947, t.2. Wrocław: Wydawnictwo Uniwersytetu Wrocławskiego.

Wendorff, B. (1995). Kościół Prawosławny. W: Kliszewicz L. (red.), Mobilizacjauchodźstwa do walkipolitycznej 1945-1990. Londyn: Polskie Towarzystwo Naukowe na Obczyźnie.

Wolsza, T. (1998). Rzad RP na obczyźnie wobec wydarzeń w kraju 1945-1950. Warszawa: Wydawnictwo DiG. 